\title{
Missional Christian Communities in Conditions of Marginality: On Finding a 'Missional Existence' in the Post-Christian West
}

\author{
Stefan Paas \\ Professor of Missiology and Intercultural Theology, Vrije Universiteit \\ Amsterdam, Amsterdam, The Netherlands \\ Professor of Missiology, Theologische Universiteit Kampen, Kampen, \\ The Netherlands \\ Research Associate, Department of Religious Studies, Faculty of Theology, \\ University of Pretoria, Pretoria, South Africa \\ s.paas@vu.nl
}

\begin{abstract}
There is a particular vulnerability to mission in the secularized societies of Western Europe. Much of this has to do with a loss of confidence, which hinders participation in the mission of God. This article presents an analysis of this vulnerability that comes from a loss of heart, and it offers possible solutions for a bold minority mission as participation in the missio Dei. This includes the de-instrumentalization of mission and rooting it in a doxological approach. Furthermore, the biblical metaphors of exile and priesthood are explored to redefine what it means to do mission from a position of joyful weakness.
\end{abstract}

\section{Keywords}

marginality - post-Christianity - West - secularization - Doxological mission priesthood 


\section{Missional Spirituality and the Crisis of Mission in the West}

There is a particular vulnerability to doing mission in the secularized societies of Western Europe. A recent study of 'church planters' in Europe mentions high and often unclear expectations, a lack of human and financial resources, continuous interaction with broken lives, and team struggles among the causes of depression and burnout for missional pioneers. While such challenges may not be specific for secularized countries, others certainly are. For example, the study also mentions the constant exposure to skepticism and cynicism about religion that these church planters have to deal with, and the relative lack of success in terms of conversion growth experienced by the majority of them as major causes of spiritual struggle. Additionally, the experience of being caught between loyalty to the established church and the need to deconstruct traditional church models in the interest of mission can lead to loneliness and exhaustion. For some church planters this amalgam of challenges results in serious doubts, the abandonment of their mission, or even loss of faith (Paas, Schoemaker 2018:370-5).

Studies like these highlight the importance of missional spirituality as opposed to a one-sided focus on structures, methods, models, and strategies. ${ }^{2}$ Focusing on pragmatic questions while taking spirituality for granted may be possible as long as our mission goes well and produces 'successes.' However, existential questions jump to the fore when Christian mission comes under pressure. Here I concur with the German missiologist Henning Wrogemann who writes (2012:73, my emphasis): “The talk of 'missionary structures' (still in the 196os) always leads us astray, because it is never structures but rather inspired, radiating - that is to say, reflecting God's light - people who do the work of mission."

While 'spirituality' can mean many things, a missional spirituality is concerned with the formation of people who are sent into the world to participate

1 'Church planters' in this study are those who have a leading role in creating new Christian communities with the purpose of reaching out to people who are not in a meaningful relationship with the church.

2 For more extensive reflections, see Paas, 'Evangelism and Methods', in: Noort et al. 2017:275-89. 
in God's mission (Bosch 2008:389-93). This formation is rooted in the selfunderstanding of the people of God, their coming to terms with what they are by virtue of their baptism. This, at least, is my working definition of a missional spirituality: to understand and trust that we are called into the mission of God. This also appears to be the main source of resilience for mission workers in the disempowering context of Western Europe. As the study cited above says (Paas, Schoemaker 2018:384-5):

Time and again, the church planters in this research emphasize how believing that it is God's mission and not ours helps them to prioritize, to accept failure, to trust God in difficulties, to open themselves up to divine guidance, and to find courage to cross boundaries. Moreover, this particular faith conviction seems pivotal in the building of a strong individual and relational spirituality.

It goes without saying that on our part participation in the mission of God is a lifelong process of learning and transformation. To parse John Zizioulas, participating in the mission of God is about us receiving and exploring our 'missional existence' as opposed to a mere 'biological existence' (Zizioulas 1997:49-65). What is true objectively ('you will be my witnesses' - Acts 1:8) must be appropriated subjectively, so that it becomes a source of joy, neighbor love, and confidence. At this point, however, major questions arise. In the postChristendom and post-Christian societies of Western Europe, 'mission' is a deeply problematic concept. While this might not directly affect the 'objective' theological level, such problems are not easily overcome on the personal and spiritual level. They are also complicated and tangled together. For example, being surrounded by people who are by and large indifferent or even hostile to Christianity (or any religion) may undermine the faith and confidence of many Christians to the extent of wondering what difference the gospel makes. Furthermore, the crumbling of Christendom opens up the question of what the purpose of mission should be. After all, a thousand years of attempts to create a Christian social order have appeared to be a mixed blessing at the very least. But if this is not to be repeated, then what should Christian mission aim for in the West?

In short, the secularization of Western culture (in the sense of the immanentization of our worldviews) is not merely an outside force to be challenged through the mission of faithful Christians; secularization is also part of the Christian life itself. It seeps through the walls of churches, and it eats away the missionary confidence of many Christians. Why should anyone today become or remain a Christian? And what difference does the Christian message make in working for the flourishing of human societies or 
the planet? The Christian missionary movement today, says James Scherer, 'is in a state of crisis because the larger community of faith of which it is a part is also in a prolonged state of crisis. [...] Gone for the most part are the simple faith, confidence, and activism' that once, for better or worse, supported the missionary movement (Scherer 1987:21). In the same vein, David Bosch begins his opus magnum Transforming Mission (1991) with an analysis of the 'contemporary crisis' of mission (Bosch 2008:1-11), and he believes that the only way forward is 'to deal with the crisis in utmost sincerity' (ibid., 7). Many developments have contributed to this missionary crisis, but perhaps the most serious of all according to Scherer is 'the crisis of faith, spirit, and theological conviction in the Western world'. Here he cites Lesslie Newbigin who wrote, on his return to Britain after a lifetime of overseas mission in India: 'A profound crisis of faith within the Western Churches has led to a loss of conviction that there is anything in the Christian faith which is so vital that without it men [sic] will perish' (Newbigin 1970, cited by Scherer 1987:33).

If this diagnosis is correct, missional communities in the secularized societies of the West face a double vulnerability. Not only do they have to cope with the problems bound up with their specific context (exaggerated expectations, limited resources, few conversions, little impact), but they may also experience the erosion of a missional theology and spirituality that once was self-evident. In fact, both aspects (little success on the one hand and an eroding missionary spirituality on the other) may interact and reinforce each other. Within the scope of this article I can only hint at some of the issues that are in play, but I believe that at least the following dimensions of a missional spirituality should be addressed with a view to contexts of deep secularization. First, it is important to rethink what Christianity is out to do in the West. In other words, we need an inspiring operational theology of salvation. Second, and linked to this, we need a clear view of purpose. If Christians evangelize, if they work for justice and a better environment, what do they want to achieve? Third, it is necessary to make theological sense of secularization. What does God have to do with it? And fourth, it is crucial to retrieve a calling that is rooted in Christian tradition and makes sense to the lives of Christians who are participating in God's mission.

There is no lack of missionary initiatives in Western European countries. In fact, all the major church bodies have embarked on 'fresh expressions' (UK), Erprobungsräume (Germany) or pioniersprojecten (The 
Netherlands). ${ }^{3}$ However, if the Dutch scene is in any way representative of other European countries, there is a worrying absence of reflection on the 'why' of mission as opposed to the 'what' and 'how' (Stoppels 2019:12-6). In other words, many missionary initiatives do not seem to be rooted in a clear and convincing theology of salvation. This may indicate several things. For starters, it may reflect the fact that the majority of secularized visitors in such missional projects participate selectively, searching for community or an interesting social project, but at the same time they are not interested in 'Jesus stuff' (Watkins, Shepherd 2014:99; Stoppels 2019:15-6). This might disempower the Christians who are involved in such a community, in the sense that they desire to initiate newcomers into Christianity but simply don't see how this can happen. In that case it is easier to keep specific Christian beliefs private and work together on the basis of shared (humanistic or social) ideals. A more sobering analysis, however, is that this focus on pragmatic issues may also point to internal secularization in the sense that (even) many Christians no longer see a relationship between their investment in the lives of other people and the gospel of Jesus Christ. They do not think too much about the 'why' of their mission, because they have lost sight of it.

For those with an Evangelical background (the majority of mission workers in Europe) the general erosion of belief in hell among Western Christians may play a role here. Much traditional evangelistic mission was predicated on the idea of a divine judgement after our death or at the end of times. To 'accept Jesus' meant that you would be saved from this fate, and that you would receive eternal bliss in God's presence. However, if not believing in Jesus does not really come with eternal consequences anymore, then why should Christians evangelize at all?

On the other hand, this lays bare how abstract much traditional evangelism has become. If the Christian message boils down to being saved from hell and living forever in heaven after we die, then this salvation becomes detached from everyday life. It should be noted here that this was not always the case, not even in the Evangelical tradition. The modern missionary movement emerged from a consciousness that European civilization and Christianity were closely linked. Missionaries debated the proper order in which these two goods should be shared with those who had been deprived from it. Should people first be elevated to a certain level of civilization before they could receive the gospel that formed the soul of this civilization? Or

3 On missional pioneering in the UK, the Netherlands, and Germany, see a.o. Paas 2016. For recent German examples, see also Erprobungsräume: Kirche anders entdecken, ed. Evangelische Kirche in Mitteldeutschland, Erfurt 2019. 
should they receive the gospel immediately, whereupon the blessings of civilization would follow organically out of the root of converted lives? Nevertheless, all were agreed on the fact that conversion to Christianity would not just lead to eternal bliss in the afterlife, but to many very concrete (albeit rather European) blessings in the here and now. ${ }^{4}$ Regardless of all that can be said about the colonial framework in which this sense of mission originated, the fact remains that these Christians had an operational theology of salvation that helped them to believe that the gospel made a difference in this life. To them, the work of mission (including the invitation to follow Jesus) was a work of love. This has been amply demonstrated by Johannes van den Berg's classic study (1956) of the motives of the missionary awakening in Great Britain (1698-1815). Van den Berg shows how Jesus' love, as those missionaries perceived it, was a holistic adventure, aimed at sharing everything they considered as the flourishing of life.

Of course, it is possible to criticize the ambivalence of this love motive, burdened as it was by paternalism and cultural arrogance. Also, from a theological point of view one might have concerns about the 'humanization of the idea of compassion' that was entailed by this love motive. Van den Berg notes that 'a strong accent on human pity could lead to a missionary philanthropy which remained below the measure of the biblical demand of love'. According to the New Testament, " $[\mathrm{t}]$ he heathen is not loved because of his pitiable state, but because he is an object of the love of Christ' (1956:195-6). There is a genuine and very Reformed concern here about the instrumentalization and immanentization of faith in God (Van der Borght 2006). Yet, one could also wonder to what extent this concern leads to a missionary practice where talk about Jesus' love remains unconnected from everything that triggers human love and compassion, like poverty, sickness, and injustice. If Christians are to appropriate their calling into God's mission subjectively, this calling should somehow interact with ordinary neighbor love that operates in the mundane realm of happiness, health, suffering, oppression, and so on. There is a real sense in which the gospel of the kingdom brings justice, peace, and joy here and now. At this point we may come across what Miroslav Volf in a seminal article called the 'nonmaterial character of salvation' in classical Protestantism. Liberation theology and Pentecostal theology, on the other hand, while different in many aspects, agree on the 'materiality of salvation' (Volf 1989). Or, as the sign says on one of the African Pentecostal churches in the south-eastern part of Amsterdam, 'Enjoy exciting church

4 Cf. the contributions in Stanley 2001. The same sentiment was dominant in the early missions to Europe when Christendom was forged. See for example Brown 1996. 
services - See prayers answered - See God at work - See the difference in your life'. God makes a difference in our lives, not just 'spiritually', but bodily, materially, and socio-economically. Volf suggests that a soteriology faithful to God's revelation in Scripture and relevant to the modern world should incorporate the distinctive salvational emphases of classical Protestantism (inner regeneration), Liberation Theology (socio-economical restoration), and Pentecostalism (healing of the body). He adds a fourth dimension, the ecological aspect. Of course, more needs to be done than simply adding these different emphases; they should be integrated in a theological unity (Volf 1989:464-7; Bosch 2008:399-400). Perhaps the Reformed emphasis on the glory of God may be the integrating principle that keeps this unity together. If mission is about God being glorified in all his creation, nothing can remain untouched. Also, the focus on God's glory is a healthy antidote against every tendency to instrumentalize the gospel in the interest of health and wealth (see below).

Much reflection is still needed on this subject. ${ }^{5}$ Yet, for a vital missional spirituality it is crucial to have a strong theology of salvation that helps Christians to connect their investment in the flourishing of people and the planet with the gospel of Jesus Christ. Neighbor love is fostered by a strong conviction that sharing the gospel is truly the loving thing to do. And this will become easier when Christians believe that the gospel is not only relevant for our soul and in the afterlife, but also for our bodies, relationships, and our lives here and now. To share the gospel is to seek the best possible life for our fellow human beings and the rest of creation. If Christians truly believe this, their calling into God's mission will become effective.

\section{3}

\section{Instrumentalization and Doxology}

There is something very paralyzing and frustrating about missionary ideals for Christian minorities in post-Christian societies. This paralysis has to do with the past. After all, in some way the societies of former Christendom exemplify a very successful Christian mission, one that has resulted in a Christianized social order. But if this social order has outlived itself, if it has created such an ambivalent and violent memory, what then does it mean

5 See, for example, Luke Bretherton's constructive discussion of 'prosperity teaching' and Pentecostalism's ambivalent relationship with capitalism, in Bretherton 2019:137-43. Cf. also Stephen Bevans's and Roger Schroeder's analysis of mission paradigms (Bevans and Schroeder 2011a:286-395; Bevans and Schroeder 2011b). 
to start mission all over again? One way to circumvent this question is to claim that Europe was never 'really' missionized. There is partial truth in this, but as a response it does not suffice. After all, if you believe that church growth and/or the transformation of society should be the purpose of mission, then there is no use denying that for a long time Christian Europe was the best example of what sinful human beings can do to approach this ideal. Christendom is in fact the most successful historical paradigm we have of a Christianized social order, and any advocate of church growth theory or mission-as-societal-transformation should wrestle with this ambiguous heritage. But if Christendom was a failure of Christian mission, as many authors nowadays claim, then the question remains: what is the purpose of Christian mission if it is not a world that has become church (church growth) or a world that has become transformed according to our best insights into what Christian values are (transformation)?

Thus, the crumbling of Christendom has led the classical models of mission into a crisis. Church growth (the conversion of as many individuals as possible) and societal transformation (the creation of institutions, laws, etc. that are based on gospel values) seem to have led to ambiguous results, to say the least. And in a context of post-Christendom they may easily become instrumentalized in the service of nostalgia or restoration. Evangelism is then assessed on the basis of its success in terms of church growth, while working for justice or peace should be justified to the extent that it brings transformation. As I have explained elsewhere, this damages missional spirituality (Paas 2019a:107-14). In a context where conversions are few and far between, and where Christians have little measurable impact, such ideals are likely to bring frustration. Also, the ideal of societal transformation based on Christian faith introduces a sense of competition. If the world should indeed be changed according to 'gospel values', Christians should be somehow 'better' than their non-Christian neighbors. They should be better social workers, scientists, fathers and mothers, nurses, and farmers. They should make a difference for the gospel, so to speak. Yet, everybody knows that Christians in post-Christian societies are generally not better than their neighbors. Thus, traditional missional models of church growth and gospel transformation draw Christians away from the actual witness of evangelism and social ministry to focusing on numbers and impact. And as such numbers and impact are often very modest indeed, Christians are tempted to lose heart, since the actual missional effort seems insignificant compared to a glorious past on the one hand and unrealistic dreams of revival on the other.

For a healthy missional spirituality, it is therefore crucial to liberate evangelism and social ministry from ideals of church growth and societal 
transformation. This can be done, theologically, by relocating mission into doxology. To participate in God's mission is first and foremost to glorify God (Wrogemann 2012; Wrogemann 2019:201-6).

The call to glorify God may easily be the most misunderstood Christian concept in the modern world. A God who is constantly seeking his glory is seen as petty, insecure - a dictator who wants to be loved because of his inner neediness. Nothing could be further from the truth. The misunderstanding comes from a false dilemma: either we are our own masters, or we serve God. In this case, God is our competitor; he demands that we pay our undivided attention to him rather than to our own good. It is then very hard indeed to avoid thoughts of a needy parent, or worse, an insecure tyrant. However, in the thought-world of the Christian gospel people are never without loyalty or worship. The crucial question is not whether we worship, but whom we worship: God or the idols. And if we worship idols, i.e. if we raise anything within creation to the level of God and give this our utmost loyalty, this is bad news indeed for our health, peace, relationships, and happiness. The call to honor God should therefore always be read as a call for our liberation. 'The glory of God is a human fully alive' (Irenaeus, Against Heresies, 4.20.7). So, the competition is not between God and us, but between God and the idols. Nostalgic idolization of Christendom very subtly replaces God with something else: a glorified past where Christians (at least, Christians who belonged to the 'established' church) were secured against criticism, ridicule, suffering, and persecution, and where all those who did not share Christian beliefs had to conform anyway. However, in a post-Christian society Christians are invited to reorient themselves to God's glory, and thus become liberated for mission.

A doxological mission is prophetic in the sense of unmasking the powers that enslave us. It helps Christians to deal with their own weakness and fatigue, as it 'provides the salutary reminder that the future of the church is in God's hands' (Wrogemann 2019:204). However, there is also an aesthetic dimension to the praise of God. God's splendor is 'reflected' by Christ, as his glory is 'reflected' by Christians (2 Cor. 3:17-18). Images of a 'shining light' and 'radiating glory' are associated with the praise of God (Wrogemann 2019:204-5). Praising God means to name him as the most Beautiful and the ultimate Good. To glorify God is to approach the point where our words falter; they stumble over the threshold of what can still be articulated. When Christians praise God, they say something like this: 'There is One who is not good for anything, but who is simply good. Period'. In this sense, doxology - by employing the language of beauty - contradicts any instrumentalization of God, any description of God in terms of usefulness or purpose. Beauty is, almost by definition, not useful. 
And so with all things divine. Doxological mission means to witness, love, and care, because these things are good in themselves. They are testimonies to God's ultimate beauty and goodness. When Christians make themselves vulnerable by sharing their innermost thoughts and beliefs, and when they go out to work for justice and the flourishing of creation, they are not primarily obsessed with results. They do these things because they reflect the love of God. The language that may be most appropriate for mission is therefore not the typical and classical language of the military or the world of business, but the language of art. Mission is like making music or painting or sculpting. It is rather silly to ask about the 'usefulness' or 'purpose' of a Bach sonata or a Rembrandt painting. This is simply not the way to engage with art. Such questions are like asking how the color 'red' smells; they may be grammatically correct, but they do not make sense whatsoever. A thing of beauty will probably not change the world, but it adds something precious nonetheless. Mission is about making small enclaves of beauty and goodness, reflecting the goodness and beauty of God, fully aware that these enclaves are vulnerable and likely to be run underfoot soon by the powers of hostility or indifference. Yet, for some time at least they give us something to love and to ponder. And wherever this work of mission leads to new converts or some changes for the good, they are seen as the first fruits of God's new creation. They are welcomed as signs of God's inbreaking kingdom, and they are loved non-instrumentally, freely.

Finally, a doxological mission does not compete with people of other religions or no religion. It glorifies God for all the goodness and beauty that is found in this world, regardless of where it comes from. Christian mission is not about outperforming non-Christians; it is about naming and affirming all that is good and praising God for it. Only thus can small Christian communities in post-Christian societies fully accept that they have become minorities and that Christendom is definitely over, and at the same time joyfully and hopefully join in the mission of God.

To participate in God's mission in a context of deep secularization will inevitably provoke the question how secularization relates to this mission. After all, if all the indicators of religious life are in decline, what then does it mean to be called into the mission of God in Europe? At the very least this seems an unsuccessful project, an undertaking that has outlived its best days. To join God's mission in contemporary Europe seems like joining a lost cause or, even worse, a failing God. Christians may be able to keep the illusion alive when they 
isolate themselves in enclaves where ecstatic rhetoric of 'revival' abounds, like in many new churches of the neo-Pentecostal kind. Or they can maintain that Europe is 'actually' very religious, even in a post-Christian era, because in good old-fashioned liberal tradition they manage to redefine football and gardening as types of 'religiosity' or 'spirituality'. In my view such strategies amount to denial. They may reflect a deeper anxiety, namely that God has abandoned us. God cannot be present in a secularized society, and thus the harsh reality of secularization must be denied.

In contexts of deep secularization, it is tempting to develop a spirituality that depends on either a binary relationship between the church and the world, or on an all too comfortable identification of church and world. The first happens in 'sectarian' approaches of secularization (Paas 2019b), the second in 'liberal' approaches. However, both strategies ignore a crucial theological question: what does God have to do with the secularization of many Western societies? Christians should not be afraid to ask this question. It allows us to think of the church-world relationship as 'dyadic, not binary, each needing the other to be truly itself'. Luke Bretherton sets this relationship in a dynamic pneumatological context, where both church and world can be 'worldly' or mediators of God's presence (2019:130). This opens up the question of what the church can learn from the world or, more straightforwardly: how Christians can meet God in the secularized world of the late-modern West. Here the biblical narratives of exile and diaspora are important hermeneutical frameworks to 'read' the context of the European church. In terms of spirituality, they may help Christians to make sense of their situation as minorities.

In 597 and 586 вСE the Babylonians conquered Jerusalem and they carried a large part of the people away into exile. The temple was destroyed, Judah's royal dynasty was finished, and the land was no longer the property of God's people. To Israel this was not just a cultural and political trauma; it was also an attack on the foundations of their faith. With the destruction of the temple and the termination of the sacrifices God disappeared from their midst; with the collapse of David's dynasty God's promise that there would always be a son of David on the throne was rendered undone; and with the occupation of the land God's promise to the patriarchs fell apart. In the words of Walter Brueggemann, this was for ancient Israel 'the end of privilege, the end of certitude, the end of domination, the end of viable political institutions, and the end of a sustaining social fabric'. He concludes: 'Not to overstate, it was the end of the life with God, which Israel had taken for granted.' (Brueggemann 200o:60). The cornerstones of faith had been shattered, God himself had not been able to protect his people against the gods of Babylon, and from 
now on many Israelites had to live among an alien people with entirely different beliefs.

Without going into detail (for this, see Paas 2019a:124-64), and without contending that the collapse of Christianity in the West is entirely comparable with the catastrophe that happened to Israel (Brueggemann 1997:1), I suggest that the stories of exile and diaspora resonate with the context of many Western Christians today. In some way these Christians have more in common with the Bible writers than with their own ancestors. Most of the authors of the Bible lived contested lives, under constant criticism and doubt; but previous generations of Western Christians lived in an unbroken Christian culture, where nobody really doubted the superiority of Christianity. To adopt the narratives of exile and diaspora as a hermeneutical lens to contexts of deep secularization suggests that secularization may be part of God's mission after all. Also, it allows for a wide spectrum of Christian responses to secularization. A sense of trauma and loss (Lamentations) is part of the exilic experience, but also an honest reflection on past and present sins - including the sins of the Christian era in Europe. On the other hand, the second Isaiah and other biblical texts show that exile is also the place where the people of God can learn that God is not linked to a specific nation, tradition, or century (Isa. 40:21-24, etc.). The world outside the promised land is not outer darkness; in fact, it is God's world. Might it be the case that some crucial lessons of a missional spirituality can only be learned through dislocation and uprooting? Can some dimensions of God's mission only be appropriated through exile?

Reflection on the exilic and diasporic traditions may teach Christians in contexts of deep secularization that God has not at all abandoned them. God renewed his missional calling to Israel through uprooting and dislocation. The same invitation may be extended to the Western church today through the crumbling of Christian institutions and their self-evident power. For missional Christians, a secularizing society may after all be a very good place to live.

\section{$5 \quad$ Priesthood as a Missional Metaphor}

So far, the following components of a missional spirituality for the context of Western Europe have been discussed: an inspiring theology of salvation, a doxological approach of mission, and developing an exilic / diasporic identity. If the first two refer to the 'why' and 'what' of mission, the last one points toward the 'where' of mission. Where are we, and how do we make theological sense of our present location in history? The final question to be addressed in this 
article denotes the 'who' of mission. Who are these people who participate in God's mission? How can they subjectively understand their identity as a people who are called to join in the mission of God? What does this 'missional existence' look like?

Building on the Old Testament traditions of the people of Israel as the 'priesthood' of the nations (Ex. 19), the apostle Peter addresses 'his' churches as 'exiles and strangers' who are at the same time a 'priesthood' (1 Pet. 2:9):

But you are a chosen people, a royal priesthood, a holy nation, God's special possession, that you may declare the praises of him who called you out of darkness into his wonderful light.

My proposal is to take this biblical priesthood metaphor as a key to exploring the missional vocation of Christians in God's world, especially in its postChristian areas (Paas 2019a:165-231). The first that must be said about it is that there is nothing particularly 'ordained' about this priesthood. By virtue of their baptism all Christians are called to be the priesthood of their neighborhoods, their cities and villages, and the world as a whole. Rather than being the label of a spiritual 'elite', the term 'priesthood' calls Christians back to humanity's original calling to be the priesthood of creation. In the first chapters of Genesis creation is presented as a temple that is built for the glory of God, where humans are appointed as priests to lead creation into worship and extend God's blessing to all creatures (Walton 2009:71-106; Walton 2015:1-4-27). 'The key point' of the creation narratives in Genesis, says Graham Tomlin (2014:75),

... is that the human race on the one hand is an emphatic part of Creation, not exalted above it, made of the dust of the ground. Yet at the same time it is summoned out of that very Creation to bear the divine image and represent God within that world. If Christ is the priest of Creation, mediating between God and the world as the divine-human Son of God, then this priestly work of mediating the love of God to the world and perfecting it is carried out first and foremost through the human race itself.

With the Orthodox theologian Alexander Schmemann, one could say that humanity's 'first, basic definition' is to be 'the priest'. This calling to cosmic priesthood is restored in Christ, the second Adam. Thus, the Church as Christ's body, takes its place as a renewed priesthood, worshiping God on behalf of all 
creation (Schmemann 1998:15, 6o-1, 92-3). In short, to participate in the mission of God is to understand our vocation as the priesthood of creation.

For a missionary spirituality this is crucial. To begin with, priests are a minority by definition. They are called out of the people to be priests for the people. By way of analogy, Christians are called out of their families, neighborhoods, workplaces, and cities to be the priests for others. The priesthood metaphor underlines that participation in God's mission sits very well with being a small minority in an overwhelmingly non-Christian society. Priesthood does not depend on numbers; it is a qualitative identity. Three ladies in a senior retirement home can be the priesthood of this place just as well as three thousand worshipers in a vibrant megachurch can be the priesthood of their city.

Second, it is important to understand the nature of this identity. Priesthood is all about mediation and representation. In the Old Testament the priests were selected out of the tribe of Levi to mediate between God and the people of Israel. They represented God to the people, and the people to God. As representatives of the people they approached God with worship ('declaring God's praises') and sacrifices (offering the best of their culture to God in worship). As representatives of God they came to the people with teaching (the Torah) and blessing. Priests will be focused on rich and deep relationships where life can be shared to the full - including the stories and beliefs we live by, and which form the seedbed for the full range of worship that Christians have to offer (praise, lament, gratitude, prophetic rage).

Third, to understand this vocation as the priesthood of creation also implies that Christians see themselves as part of a community. When Peter speaks about the 'royal priesthood' he uses a collective term (hierateuma). He speaks about the Church as a priesthood community. This runs counter to a certain kind of hyper-Protestantism where Christian identity is rooted first and foremost in an individual relationship with God. If, and only if this relationship is settled Christians may (or may not) choose to cooperate and form a community they call 'church' or 'congregation'. Essentially, this community does not add anything to Christian identity. It is usually defended in terms of pragmatic usefulness (mutual support, cooperation in mission, etc.). In this hyper-Protestantism 'church' comes in handy, but it is not necessary. However, when Christian identity is located primarily in the community that is the priesthood, then God has a relationship with the Church first, and through the Church with individual Christians. The Christian priesthood is not the sum of individual priests, but it is a communal identity through which individual Christians derive their identity as priests. There 
is no priestly existence, and thus no participation in God's mission, outside the community of the Church (Christ's body). And this is so, 'because salvation is, in the first place, a distinct form of social existence. To be saved is to be made part of a new people and a new politics, the body of Christ' (Stone 2007:188). In short, understanding their calling as a priesthood drives Christians to seeking community, to build strong and loving relationships among each other, but also with others - since the boundaries of the Church are never clearly set. We know where salvation begins, but we do not know where it ends. Out of the eucharistic celebration of Christ's death and resurrection relationships grow, extend, and ramify endlessly into the world. To be a priest is to be a relational being.

Finally, the representational dimension of the priesthood means something very important for missional and evangelistic practice. If Christians are the priesthood of creation, they are also worshiping God on behalf of their friends and neighbors. Of course, Christians will invite other people to join them in worship, to become fellow priests. That is what evangelism is about: to invite people to discover their calling as human beings and to accept their identity in Christ as priests who are given to God and their neighbors for love and service. And when this happens, there will be joy among the angels, and the Church will welcome these new priests as the first fruits of the new creation. Yet, many of these friends and neighbors will say 'no'. If that happens, however, it is not the end of the story. Christians will remain the priests of their families and friends, even after these have declined the evangelistic invitation. There is a countercultural element here, as modern Western cultures (including most Christians) are so deeply individualized that the concept of 'representation' does not make much sense to even the most pious Christians (or perhaps especially not to them). However, if we learn to understand our humanity as relational to the core, we might be able to understand why the Bible writes about the righteous Job who sacrificed to God every morning for all his children. For Job said: 'It may be that my children have sinned, and cursed God in their hearts' (Job 1:5). This offering on behalf of others is intelligible only if we accept that a biblical picture of the relationship between God and humans is covenantal in the first place. In other words, God relates not just with individual believers, but through them with all those who are joined with these believers through loving relationships. A New Testament example is found in 1 Corinthians 7 , where the apostle Paul urges Christians in 'mixed' marriages not to divorce, 'for the unbelieving husband is made holy through his wife, and the unbelieving wife is made holy through her husband. Otherwise, your children would be 
unclean, but as it is, they are holy' (v. 14). In an individualized worldview there is no way to make sense of this 'holiness' of unbelievers. However, it makes perfect sense as soon as we understand that God gives his salvation not to isolated individuals, but to humans-in-relationship. I am not here speculating about the eternal destiny of those who have rejected Christ, but this relational nature of our createdness should give hope to Christians who are involved in God's mission. Apparently, the reach of God's salvation does not depend on individual assent only; there is a mystery about it of abundance and surprise. To Christians who have lost heart about the possibilities of evangelism in a post-Christian society this may be a source of hope: even if you are the only follower of Christ in your family or your workplace, your work as a priest is not in vain. God works his salvation through the priesthood of the Church into marriages, families, friendships, neighborhoods, collegial bonds, and so on - making them 'holy', and thus in some sense part of the holy priesthood. You can worship 'for' them, 'on behalf of' them, out of your loving relationships with them.

\section{Conclusion}

In his bestselling book The Second Mountain, New York Times columnist David Brooks reports on his discovery of the 'moral life' (Brooks 2019). It is a life that no longer revolves around career wins, high status, and nice things, but is committed to finding meaning. People who have embarked on this road to a meaningful life have made strong commitments to a 'vocation' (something to live for that is bigger than ourselves), a 'spouse and family' (a strong and intimate relationship characterized by faithfulness and love), a 'philosophy or faith' (Brooks writes about his own conversion to Christianity), and a community (being involved in neighborhoods in a wider sense, to make friends with people who are not like you).

In the same way, to grow towards a 'missional existence' is to discover what makes life worth living. It is about developing a meaningful life by finding our role in the mission of God. Brooks' dimensions of a 'moral life' are very similar to what I have described above. A missional existence is bound up with accepting our vocation as the priesthood of creation. It is to know ourselves as persons-in-community, and to develop strong and loving relationships with people around us, and, for that matter, with our urban gardens, our cattle and pets, our lawns and meadows, and all of God's creation. And to explore our identity as exiles in a world that is God's world after all, and the object of his 
mission, is what it means to have a faith that helps us to make sense of Christian life in a post-Christian society. Brooks shows that in some ways this 'missional existence' resonates with more widely shared sentiments in Western secularized societies.

\section{References Cited}

Berg, Johannes, van den (1956). Constrained by Jesus' Love: An Inquiry into the Motives of the Missionary Awakening in Great Britain in the Period between 1698 and 1815. Kampen: Kok.

Bevans, Stephen B. and Roger P. Schroeder, eds. (2011a). Constants in Context: A Theology of Mission for Today. Orbis: Maryknoll (4th ed.).

Bevans, Stephen B. and Roger P. Schroeder, eds. (2011b). Prophetic Dialogue: Reflections on Christian Mission Today. Orbis: Maryknoll.

Borght, E.J., van der ed. (2006). Religion without Ulterior Motive. Studies in Reformed Theology, 13. Brill: Leiden.

Bosch, David J. (2008). Transforming Mission: Paradigm Shifts in Theology of Mission. Orbis: Maryknoll (24th ed.).

Bretherton, Luke (2019). Christ and the Common Life: Political Theology and the Case for Democracy. Eerdmans: Grand Rapids.

Brooks, David (2019). The Second Mountain:The Quest for a Moral Life. Penguin Books: New York.

Brown, Peter (1996). The Rise of Western Christendom: Triumph and Diversity, A.D. 20o100o. Blackwell: Oxford.

Brueggemann, Walter (1997). Cadences of Home: Preaching among Exiles, Louisville: Westminster.

Brueggemann, Walter (2000). Deep Memory, Exuberant Hope: Contested Truth in a Post-Christian World. Minneapolis: Fortress Press.

Newbigin, Lesslie (1970). "Mission to Six Continents." In Harold Fey, ed. The Ecumenical Advance: A History of the Ecumenical Movement, Volume 2, 1948-1968. London: SPCK:171-197.

Noort, Gerrit et al., eds. (2017). Sharing Good News: Handbook on Evangelism in Europe, wCC: Geneva.

Paas, Stefan (2016). Church Planting in the Secular West: Learning from the European Experience. Eerdmans: Grand Rapids.

Paas, Stefan (2019a). Pilgrims and Priests: Christian Mission in a Post-Christian Society, SCM: London.

Paas, Stefan (2019b). "The Countercultural Church: An Analysis of the Neo-Anabaptist Contribution to Missional Ecclesiology in the Post-Christendom West." Ecclesiology 15:271-89. 
Paas, Stefan and Marry Schoemaker (2018). "Crisis and Resilience Among Church Planters in Europe." Mission Studies 35, 3:370-5.

Scherer, James A. (1987). Gospel, Church, \& Kingdom: Comparative Studies in World Mission Theology. Eugene: Wipf \& Stock.

Schmemann, Alexander (1998). For the Life of the World: Sacraments and Orthodoxy. Crestwood: St. Vladimir's Seminary Press.

Stanley, Brian ed. (2001). Christian Missions and the Enlightenment. Routledge: London. Stone, Bryan (2007). Evangelism after Christendom: The Theology and Practice of Christian Witness. Grand Rapids: Brazos Press.

Stoppels, Sake (2019). Heil zien in missionaire initiatieven: Een zoektocht naar de theologie achter nieuwe vormen van geloofsgemeenschap. Ede: Lectoraat Zingeving CHE.

Tomlin, Graham (2014). The Widening Circle: Priesthood as God's Way of Blessing the World. London: SPCK.

Volf, Miroslav (1989). "Materiality of Salvation: An Investigation in the Soteriologies of Liberation and Pentecostal Theologies." Journal of Ecumenical Studies, 26, 3:447-67.

Walton, John (2009). The Lost World of Genesis One: Ancient Cosmology and the Origins Debate. Downers Grove: IVP Academic.

Walton, John (2015). The Lost World of Adam and Eve: Genesis 2-3 and the Human Origins Debate. Downers Grove: IVP Academic.

Watkins, Clare and Bridget Shepherd (2014). "The Challenge of 'Fresh Expressions' to Ecclesiology: Reflections from the Practice of Messy Church." Ecclesial Practices (1), 92-110.

Wrogemann, Henning (2012). Den Glanz widerspiegeln: Vom Sinn der christlichen Mission, ihren Kraftquellen und Ausdrucksgestalten. Interkulturelle Impulse für deutsche Kontexte. Berlin: LIT Verlag.

Wrogemann, Henning (2019). "Christian Mission and Globalization: Current Trends and Future Challenges." In John G. Flett and David W. Congdon, eds. Converting Witness: The Future of Christian Mission in the New Millennium. Lanham: Lexington Books.

Zizioulas, John D. (1997). Being as Communion: Studies in Personhood and the Church. Crestwood: St.Vladimir's Semianry Press.

\section{摘要}

在西欧世俗化社会里, 对宣教具有某种脆弱性。这在很大程度上与失去信心有关, 这阻碍了对上帝使命的参与。本文分析了这种来自失去信心的脆弱性, 它为参与 missio Dei 的大胆的少数人的宣教提供了可能的解决方案。这包括使宣教非工具 化、并以敬拜的方法扎根。此外, 探索了圣经中关于流放和圣职的隐喻, 并从喜乐 的柔弱中, 重新定义宣教意味着什么。 


\section{Resumen}

La misión en las sociedades secularizadas de la Europa occidental sufre una vulnerabilidad particular. Mucho de esto tiene que ver con una pérdida de confianza que dificulta la participación en la misión de Dios. Este artículo presenta un análisis de esta vulnerabilidad que proviene del desánimo, y ofrece posibles soluciones para una misión minoritaria audaz como partícipe en la missio Dei. Esto incluye la des-instrumentalización de la misión y el su enraizamiento en un enfoque doxológico. Además, las metáforas bíblicas del exilio y del sacerdocio se exploran para redefinir lo que significa hacer la misión desde el lugar de la debilidad gozosa. 